\title{
Reduction of Breynia subgenus Hemisauropus to \\ $B$. section Cryptogynium and discussion of the \\ B. quadrangularis complex (Phyllanthaceae)
}

\author{
P.C. van Welzen ${ }^{1,2}$
}

Key words

Breynia section Cryptogynium Breynia quadrangularis complex Euphorbiaceae

Phyllanthaceae

Sauropus
Abstract Breynia subgenus Hemisauropus is reduced to Breynia section Cryptogynium. Arguments are given to regard the Breynia quadrangularis complex as a single species.

Published on 12 June 2017

\section{INTRODUCTION}

The genera Phyllanthus L., Breynia J.R.Forst. \& G.Forst., Glochidion J.R.Forst. \& G.Forst. and Sauropus Blume form a clade in the phylogeny of the Phyllanthaceae (Kathriarachchi et al. 2006), where Phyllanthus is paraphyletic. Two options exist to address the paraphyly. Phyllanthus can be made monophyletic by either subsuming the non-included genera into a gigantic Phyllanthus (Hoffmann et al. 2006) or Phyllanthus may be split into morphologically recognisable monophyletic genera (Van Welzen et al. 2014). Van Welzen et al. (2014) opt for the latter solution and based on phylogenetic evidence (Pruesapan et al. 2012) they recognised the genera Synostemon F.Muell. (formerly united with Sauropus) and Breynia (including the nonSynostemon part of Sauropus, also known as Sauropus s.str.).

The recent phylogeny of Breynia (Pruesapan et al. 2012) shows that the clade splits basally into two groups, recognised as the subgenera Breynia and Sauropus Welzen \& Pruesapan. The subgenus Breynia clade splits again in two groups, recognised as section Breynia (equalling the genus Breynia before union with Sauropus) and section Cryptogynium (Müll.Arg.) Welzen \& Pruesapan (Van Welzen et al. 2014). The infrageneric classification thus reflects the phylogeny.

Shortly after Hoffmann et al. (2006) published their recommendation to unite all genera into Phyllanthus, Chakrabarty \& Balakrishnan (2009) made all combinations under Phyllanthus for all Indian species of Breynia and Sauropus, reverting these to Breynia (Chakrabarty \& Balakrishnan 2012) as soon as Pruesapan et al. (2012) published the idea to subdivide Phyllanthus.

Recently, Chakrabarty \& Balakrishnan (2015) raised Breynia section Cryptogynium (Van Welzen et al. 2014) to subgeneric rank as B. subgenus Hemisauropus (Müll.Arg.) Chakrab. \& N.P.Balakr. The only argument given is that it facilitates the recognition of the small-leaved species of Breynia. This decision is unfortunate for three reasons.

\footnotetext{
${ }_{1}$ Naturalis Biodiversity Center, research group Biodiversity Discovery, P.O. Box 9517, 2300 RA Leiden, The Netherlands;

e-mail: peter.vanwelzen@naturalis.nl.

2 Institute of Biology Leiden, Leiden University, P.O. Box 9505, 2300 RA Leiden, The Netherlands.
}

The small-leaved group of Breynia species also contains species with larger leaves (e.g., B. pierrei (Beille) Welzen \& Pruesapan, B. subterblanca (C.E.C.Fisch.) C.E.C.Fisch.) and is, as a group, not really recognisable by the size of the leaves. Moreover, section Breynia, the sister-group of section Cryptogynium, also only comprises small-leaved species. Therefore, the argument by Chakrabarty \& Balakrishnan (2015) is invalid. The raise to subgeneric level disrupts the phylogenetic information (Pruesapan et al. 2012, Van Welzen et al. 2014), because Chakrabarty \& Balakrishnan (2015) only retain section Breynia, while section Cryptogynium (their subgenus Hemisauropus) is of equal standing. In their classification it seems that their subgenus Hemisauropus equals subgenus Sauropus and might be a sister-group, which it is not.

Finally, the name Hemisauropus, is very unfortunate (but nomenclaturally necessary at subgenus level). In former classifications (e.g., Airy Shaw 1969), Hemisauropus only referred to a part of current section Cryptogynium, containing a group of species with staminate flowers with partly infolded sepals grown together via the midrib, absent scales and large stamens. However, this Hemisauropus group, though recognisable, was found to be polyphyletic as $B$. granulosa (Airy Shaw) Welzen \& Pruesapan was resolved in the Breynia phylogeny as separate from the rest of the 'Hemisauropus' group (f. 3 in Van Welzen et al. 2014; 'Hemisauropus' group represented by $B$. kerrii (Airy Shaw) Welzen \& Pruesapan, both species indicated by the abbreviation HEM). This is supported by pollen characters. Breynia granulosa has Sauropus pollen type 4 (as Sauropus granulosus Airy Shaw in Sagun \& Van der Ham 2003), while the 'Hemisauropus' group has Sauropus pollen type 3 (Sagun \& Van der Ham 2003).

Especially the first two reasons compel me to restore subgenus Hemisauropus to section Cryptogynium:

\section{Breynia section Cryptogynium (Müll.Arg.) Welzen \& Pruesa- pan (Phyllanthaceae)}

Breynia section Cryptogynium (Müll.Arg.) Welzen \& Pruesapan in Van Welzen et al. (2014) 89. - Sauropus Blume section Cryptogynium Müll.Arg. (1863) 73. - Type: Sauropus rigidus Thwaites [= Breynia quadrangularis (Willd.) Chakrab. \& N.P.Balakr.] 
Ceratogynum Wight (1852) 26, t. 1900. - Type: Ceratogynum rhamnoides Wight [= Breynia quadrangularis (Willd.) Chakrab. \& N.P.Balakr.].

Sauropus Blume sect. Hemisauropus Müll.Arg. (1866) 243. - Sauropus Blume subgenus Hemisauropus (Müll.Arg.) Pax \& K.Hoffm. (1922) 225. Breynia J.R.Forst. \& G.Forst. subgenus Hemisauropus (Müll.Arg.) Chakrab. \& N.P.Balakr. (2015) 416. - Type: Sauropus rostratus Miq. [= Breynia temii (Welzen \& Chayam.) Welzen \& Pruesapan]

More references for each name can be found in Van Welzen et al. (2014).

\section{BREYNIA QUADRANGULARIS COMPLEX}

It is obvious that Chakrabarty and colleagues prefer to maintain entities in the Breynia quadrangularis complex (sect. Cryptogynium) as distinct species (Chakrabarty \& Gangopadhyay 1996, under Sauropus; Chakrabarty \& Balakrishnan 2015), while I (Van Welzen 2003, under Sauropus; Van Welzen et al. 2014) regard them as one single, variable species. These species were also partly used as infraspecific entities (var. compressus, var. puberulus; see Van Welzen 2003). Time will tell who is correct. I only would like to add three remarks to the discussion.

The identification table in Chakrabarty \& Balakrishnan (2015) nicely shows that the variability is more or less continuous and the differences do not always seem to be very distinct, especially not between their $B$. compressa (Müll.Arg.) Chakrab. \& N.P.Balakr. and B. concinna (Collett \& Hemsl.) Chakrab. \& N.P.Balakr. Particularly sepal shapes are difficult as a character, because sepals can become, by exception, free and narrow. This is discussed in Van Welzen et al. (2014: 88), where an example for $B$. androgyna (L.) Chakrab. \& N.P.Balakr. is provided. What is not obvious from the discussion by Chakrabarty \& Balakrishnan (2015), is whether or not the whole distribution and variability of the species complex was covered, as they focus on India. It is unlikely that they have seen material from the species' full range, because they do not refer to it and they do not acknowledge loans from other herbaria. Quite a number of specimens are known from outside India (see Van Welzen 2003, map 15 under Sauropus quadrangularis). If the complete variability is not covered then the status of the taxa recognised by Chakrabarty \& Balakrishnan (2015) is uncertain as intermediates specimens occur outside and even inside India (Van Welzen 2003: 367, note 4).

Chakrabarty \& Balakrishnan (2015) discuss only differences in morphology. A synthetic approach, also taking into account similarities, may be more clarifying. All other species in section Cryptogynium and subgenus Sauropus have pistillate flowers with horizontal, partly split stigmas resembling a crescent moon. The pistillate flowers in the quadrangularis group have erect, non-crescent moon-like stigmas. This obvious apomorphy, together with transitions between forms, is especially for me important to regard all forms as one, though variable, species.

Describing variability is difficult. Two extremes are presented here: splitting into various species (Chakrabarty \& Balakrishnan 2015) or uniting all forms into one (Van Welzen et al. 2014) with a description of the variability via notes (Van Welzen 2003). The best way forward will be to use molecular data in a phylogeographic approach to see if the complex contains a single or multiple species. Until such studies have been performed, disagreements like these are likely to persist.

Acknowledgements Jan-Frits Veldkamp is thanked for drawing my attention to the publication of Chakrabarty \& Balakrishnan (2015). The reviewers and editor are thanked for their constructive remarks.

\section{REFERENCES}

Airy Shaw HK. 1969. Notes on Malesian and other Asiatic Euphorbiaceae. CI. New or noteworthy species of Sauropus BI. Kew Bulletin 23: 42-55. Chakrabarty T, Balakrishnan NP. 2009. Transfer of Indian species of Breynia, Glochidion and Sauropus to Phyllanthus (Phyllanthaceae) - new combinations and new names. Journal of Economic and Taxonomic Botany 33: 712-716.

Chakrabarty T, Balakrishnan NP. 2012. Nineteen new combinations and a new name in Breynia J.R.Forst. \& G.Forst. (Phyllanthaceae) from Indian subcontinent. Bangladesh Journal of Plant Taxonomy 19: 119-122.

Chakrabarty T, Balakrishnan NP. 2015. Reinstatement of four taxa synonymized under Breynia quadrangularis with proposal for a new subgenus Hemisauropus (Phyllanthaceae). Journal of Economic and Taxonomic Botany 39: 415-419.

Chakrabarty T, Gangopadhyay M. 1996. The genus Sauropus Blume (Euphorbiaceae) in the Indian subcontinent. Journal of Economic and Taxonomic Botany 20: 513-545.

Hoffmann P, Kathriarachchi H, Wurdack KJ. 2006. A phylogenetic classification of Phyllanthaceae (Malpighiales; Euphorbiaceae sensu lato). Kew Bulletin 61: 37-53.

Kathriarachchi H, Samuel R, Hoffmann P, et al. 2006. Phylogenetics of tribe Phyllantheae (Phyllanthaceae; Euphorbiaceae sensu lato) based on nrITS and plastid matK DNA sequence data. American Journal of Botany 93: 637-655.

Müller Argoviensis J. 1863. Euphorbiaceae. Vorläufige Mitteilungen aus dem für DeCandolle's Prodromus bestimmten Manuscript über diese Familie. Linnaea 32: 12-126.

Müller Argoviensis J. 1866. Euphorbiaceae. In: De Candolle A (ed), Prodromus Systematis Naturalis Regni Vegetabilis 15, 2: 189-1260. Masson \& Filii, Paris.

Pax F, Hoffmann K. 1922. Euphorbiaceae-Phyllanthoideae-Phyllantheae. In: Engler A (ed), Das Pflanzenreich IV.147.xv: 215-226. Engelmann, Leipzig. Pruesapan K, Telford IRH, Bruhl JJ, et al. 2012. Phylogeny and proposed circumscription of Breynia, Sauropus and Synostemon (Phyllanthaceae), based on chloroplast and nuclear DNA sequences. Australian Systematic Botany 25: 313-330.

Sagun VG, Van der Ham RWJM. 2003. Pollen morphology of the Flueggeinae (Euphorbiaceae, Phyllanthoideae). Grana 42: 193-219.

Van Welzen PC. 2003. Revision of the Malesian and Thai species of Sauropus (Euphorbiaceae: Phyllanthoideae). Blumea 48: 319-391.

Van Welzen PC, Pruesapan K, Telford IRH, et al. 2014. Phylogenetic reconstruction prompts taxonomic changes in Sauropus, Synostemon and Breynia (Phyllanthaceae tribe Phyllantheae). Blumea 59: 77-94.

Wight R. 1852. Icones Plantarum Indiae Orientalis 5. Franck \& Co., Madras. 